\title{
Technology and Return Predictability ${ }^{1}$
}

\author{
Jiaping Qiu \\ DeGroote School of Business \\ McMaster University \\ 1280 Main Street West, Hamilton, ON L8S 4M4 \\ 905.525.9140 \\ qiu@mcmaster.ca \\ Jin Wang \\ School of Business and Economics \\ Wilfrid Laurier University \\ 75 University Avenue West, Waterloo, ON N2L 3C5 \\ 519.884.0710 ext. 2660 \\ jwang@wlu.ca \\ Yi Zhou \\ Department of Finance \\ College of Business \\ San Francisco State University \\ 1600 Holloway Avenue, San Francisco, CA, 94132 \\ 415.338.2661 \\ yizhou88@sfsu.edu
}

First version: July 10, 2016

This version: March 12, 2018

\begin{abstract}
This paper finds significant predictability in stock returns across technology-linked firms. Using patent-holding information to identify firms' technological linkage, we show that a long-short equity trading strategy sorted on lagged returns of technology-linked firms yields monthly alphas of around 105 basis points. The findings are robust to a number of specifications and are not driven by industry predictability, customer-supplier relationships, and strategic alliances. We provide supportive evidence that investors' limited attention to technological linkages contributes to the return predictability across technology-linked firms. Our study uncovers technological relatedness as an important information linkage between firms.
\end{abstract}

Keywords: Technological Linkage, Stock Return Predictability, Limited Attention.

JEL classification: G11, G12, G14

${ }^{1}$ We thank Michael Brennan and Lauren Cohen for helpful discussion. 


\title{
Technology and Return Predictability
}

\begin{abstract}
This paper finds significant predictability in stock returns across technology-linked firms. Using patent-holding information to identify firms' technological linkage, we show that a long-short equity trading strategy sorted on lagged returns of technology-linked firms yields monthly alphas of around 105 basis points. The findings are robust to a number of specifications and are not driven by industry predictability, customer-supplier relationships, and strategic alliances. We provide supportive evidence that investors' limited attention to technological linkages contributes to the return predictability across technology-linked firms. Our study uncovers technological relatedness as an important information linkage between firms.
\end{abstract}

Keywords: Technological Linkage, Stock Return Predictability, Limited Attention.

JEL classification: G11, G12, G14 


\section{Introduction}

The importance of technology in explaining stock returns has attracted increasingly attention in the asset pricing literature. Recent studies show that, at the aggregate level, technology shocks could have strong predictive power for market returns and premia (e.g., Garleanu, Panageas, and Yu (2012), Hsu (2009), Paster and Veronesi (2009)). At the firm level, technologies have been found to be related to the cross-sectional variation of stock returns (e.g., Gomes, Kogan, and Zhang (2003), Hirshlefier, Hsu, and Li (2013, 2017), Praveen and Li (2016)). Despite welldocumented evidence that technology is an important factor in determining a firm's market valuation, little is known about whether and to what extent information about valuations are transmitted across technologically related firms.

This research question is interesting because technological relatedness between firms is an important economic linkage between firms that is distinctive from their product relatedness (e.g., Bloom, Schankerman, and Van Reenen (2013); Qiu and Wan (2015)). Firms producing different products (in different industries) could have strong technological linkages while firms producing similar products (in the same industry) might have weak technological linkages. For example, the International Business Machine Corp. (SIC code 7370 - computer programming, data processing, and other computer-related services) and AT\&T Corp. (SIC code 4813 - telephone communications) do not compete in the same product market. Yet, IBM and AT\&T are highly technologically related, as evidenced by their frequently cross-cited patents. On the other hand, Pfizer and Genentech, two leading pharmaceutical companies, are vying for dominance in the product market with similar products but are relatively distant in the technology space, with low cross-cited patents. This is because Pfizer relies on a traditional pharmaceutical research and works with chemical compounds; Genentech, in contrast, uses advances in genetics research and manufactures products in living organisms. 
With the increasingly important role of technology in determining a firm's valuation, examining the transmission of valuation information through technologically related firms helps us understand if and how investors incorporate this implicit yet important economic linkage into asset pricing and its implications for market efficiency. If investors react to the publicly available information of technology-linked firms, firm prices will adjust immediately when the news about technology-linked firms is released into the market. Since investors have limited ability to collect information and market participants are unable to meet the rational expectations to extract information from prices, news will travel slowly across assets. This "limited attention" (Kahneman (1973)) requires individuals to allocate their cognitive resources to one set of tasks at a trade-off of another set of tasks. Investors with limited attention could overlook the technological relatedness between firms that is implicit and complex. If stock prices do not promptly incorporate news about technology-linked firms, a firm's stock price could underreact to positive (negative) news involving technology-linked firms and generate a positive (negative) subsequent price drift.

In this paper, we investigate how shocks to the valuations of a firm's technologically related firms translate into the shock to the firm in its stock prices and real performance. Following the literature (Jaffe (1986), Bena and Li (2012)), we measure technology relatedness between firms using technological proximity, which captures any pair of firms' technology overlaps using their patenting information. For each firm, we identify a portfolio of technologylinked firms if their technology proximity is in the top 20 percentile in a year. For each month, we sort stocks according to the return on their technology-linked portfolio, which is the average return of each firm's technology-linked firms weighted by the technological proximity. We find that a monthly strategy of buying firms that are technologically linked had the most positive 
returns (the highest quintile) in the previous month and selling firms that are technologically linked had the most negative returns (the lowest quintile) yields the FF-3 alpha of around 105 basis points per month, or an annualized return of $12.6 \%$ per year. We refer to this return predictability as technology predictability.

We test for a number of explanations for the technology predictability results. It could be that technology predictability is unrelated to investors' limited attention to the technology link, but driven by the firm's own past returns, which may be contemporaneously correlated with the technology-linked firms' past returns. In this case, the average past return of the technologylinked firms is simply a noisy proxy for the firm's own past return. We control for the firm's own past returns and find that controlling for own firm predictability does not affect the magnitude or significance of the technology predictability results. Alternatively, the results could be driven by industry momentum, which involves buying stocks from previously winning industries and selling stocks from previously losing industries. This is more profitable than buying past winning stocks and selling past losing stocks (Moskowitz and Grinblatt (1999)). The result could also be driven by a lead-lag relationship that a firm's stock price shows a delayed reaction to the price innovations of other firms (Lo and MacKinlay (1990), Hou and Moskowitz (2005), and Hou (2006)). Explicitly controlling for these effects does not have a significant impact on the magnitude or significance of the technology predictability. Finally, a recent paper by Menzly and Ozbas (2006) uses upstream and downstream definitions of industries to define cross-industry predictability. We find that controlling for cross-industry predictability does not affect the technology predictability results either.

If limited investor attention is driving the return predictability along the technology linkage, then the magnitude and significance of the return predictability should depend on the 
extent of limited attention. We use mutual funds' joint holdings of the technology-linked firms to identify a subset of firms in which investors are a priori more likely to collect information on both of the technologically related firms and hence to be more attentive to the technology link. We show that technological predictability is indeed significantly more pronounced when mutual funds have less joint holding. We also show that, for firms with smaller capitalization, lower institutional ownership, and lower numbers of analyst following, the long-short portfolio returns are significantly stronger, suggesting that that return predictability is indeed more severe for stocks for which attention is likely to be lower.

Our paper uncovers an implicit yet important informational linkage in firm valuations that has not been documented in the literature. The extant literature has focused on information transmission in stock return through explicit economic relationships. Menzly and Ozbas (2010) show that stocks that are in economically related supplier and customer industries cross-predict each other's returns. Cohen and Frazzini (2006) documented cross-predictability in firms with supplier-customer relationships; lagged suppliers' stock returns are positively correlated with customers' stock returns. Addoum, Kumar, and Law (2014) show that value-generation information is geographically linked and offers predictability about future returns. Cao, Chordia, and Lin (2015) found cross-predictability among firms who are strategic alliances. With the rising importance of technology in a knowledge-based economy in determining a firm's competitiveness, growth opportunities, and valuation, uncovering and understanding the informational linkage through technology relatedness has important implications for market efficiency and investor welfare.

Prior research has also examined how complexity information could affect information transmission in the stock market. Cohen and Lou (2012) document substantial return 
predictability from the set of easy-to-analyze firms to their more complicated peers. To the extent that technological relatedness provides complicated information for investors, our results provide new evidence that, given investors' limited processing capacity, complexity in information processing can lead to a significant delay in the impounding of information into asset prices.

This paper is also related to the growing literature on the peer effects of corporate finance policies. While prior literature focuses primarily on how a firm's financing policies could be significantly influenced by the choices of its industrial peers (e.g., Leary and Roberts (2014)), the valuation spillover effects through the technology channel documented in our study suggest that technology relatedness is an important dimension to define a firm's peers.

The remainder of the paper is organized as follows. Section 2 describes the data. Section 3 establishes the main technology predictability result, provides robustness checks and considers alternative explanations, and explores the variation in limited attention and technology predictability. Section 4 concludes.

\section{Data}

We obtain data regarding monthly stock returns, stock prices, stock trading volume, and shares outstanding from the CRSP. To be included in the sample, the stocks must be traded in NYSE, NASDAQ, or AMEX, with the price greater than $\$ 1$. We obtain firms' financial information from COMPUSTAT, analyst coverage and earnings forecasts from the Institutional Brokers' Estimate System (I/B/E/S), quarterly institutional holdings (13F Filings) from Thomson Financial, and returns on common risk factors and risk-free rates from Kenneth French's website.

We obtain patent information from Kogan, Papanikolaou, Seru, and Stoffman (2014). The dataset provides information about patent number, patent assignee, patent filing date, patent 
award date, and CRSP identifier matched to patent assignee. We obtain patent class information from the Google Patents database. Each patent is assigned to one of the 426 patent classes defined by United States Patent and Trademark Office.

Our patent data covers the period between 1968 and 2011 (528 months). Our sample ends in 2011, because year 2010 is the last year for which patent information is available. We rebalance portfolios each month in calendar year $t$ according to the firms' patent information up to the end of calendar year $t-1$.

Following Jaffe (1986), we use technological proximity to measure the technological relatedness between two firms:

$$
\text { Technological Proximity }{ }_{i, j, t}=\frac{S_{i, t} S_{j, t}^{\prime}}{\sqrt{S_{i, t} S_{i, t}^{\prime} \sqrt{ } S_{j, t} S_{j, t}^{\prime}}}
$$

where the vector $S_{i, t}=\left(s_{i, 1, t}, \ldots, s_{i, k, t}, \ldots, s_{i, K, t}\right)$ captures the scope of innovation activity through patent output of firm $i$, and the vector $S_{j, t}=\left(s_{j, 1, t}, \ldots, s_{j, k, t}, \ldots, s_{j, K, t}\right)$ captures the scope of innovation activity through patent output of firm $j$. The subscript $k$ in $(1, . . K)$ is the technology class index. The scalar $s_{i, k, t}\left(s_{j, k, t}\right)$ is the ratio of the number of awarded patents to firm $i(j)$ in technology class $k$ with award years from $t-3$ to $t-1$ to the total number of awarded patents to firm $i(j)$ awarded over the same period. Technology proximity is a measure with annual frequency. For any firm pairs in calendar year $t$, the two firms are deemed as technology linked if their technology proximity is in the top 20 percentile in year $t$. Our results are robust to other alternative percentile cutoffs.

\section{[Table 1 about here]}

Table 1 shows the summary statistics for our sample over time. The number of unique firms that have at least one technology-linked firms rises from 627 in 1968 to 1,106 in 2011. In total, we have close to 50,000 firm-month observations. An average sample firm has 51 
technology-linked peer firms. The average technology proximity between a firm pair increases from 0.29 in 1968 to 0.55 in 2011 . While the percentage of technology-linked firms that are also in the same FF 48 industry increases from 15.69\% in 1968 to 38.08\% in 2011, most technologylinked firms are in different industries, suggesting that technological proximity captures the economic link between a firm pair that differs from traditional product market link. The average technological proximity between firm pairs in the same FF48 industry is 0.44 , whereas that between firms pairs in different FF48 industries is 0.39, again suggesting that technology proximity captures an economic link between firm pairs that transcends industries.

\section{Results}

\subsection{Basic Results}

Table 2 presents the basic results of this paper. At the beginning of each month $t$, we calculate the average return of each firm's technology-linked firms in month t-1, weighted by technology proximity. Then we form five portfolios by separating stocks into quantiles according to the average return of its linked firms. The portfolios in quintiles 1 to 5 include stocks whose technology-linked firms have highest, high, median, low, and lowest returns in month t-1, respectively. Columns (1) to (4) report the average returns of portfolios in month t in each quantile. Column (5) reports the returns in month $t$ of a zero-cost portfolio that buys stocks in the top quintile and sells stocks in the bottom quintile. We refer to this strategy as technology-based strategy and the corresponding long-short portfolio as technology-based long-short portfolio. ${ }^{2}$ In Panel A and B, we equal and value weight stocks in each quintile portfolio respectively and rebalance the portfolios monthly.

\footnotetext{
${ }^{2}$ To be included in the portfolio, a firm must have a technologically related firm and non-missing closing stock price at the end of the previous month. Also, we set a minimum liquidity threshold by not allowing trading in stocks with a closing price at the end of the previous month below $\$ 1$. This ensures that portfolio returns are not driven by the microstructure-related bias from illiquid securities. The similar criterion has been used by Cohen and Frazzini (2008). and Cao, Chordia and Lin (2015).
} 
[Table 2 about here]

Table 2 shows that the stock returns of a firm's technologically linked firms have significant predictability on the firm's future stock returns. The raw returns of equal-weighted (EW) portfolios increase monotonically from the quintile of lowest returns of technology-linked firms to the quintile of highest returns of technology-linked firms. The EW technology-based strategy that longs the stocks whose technology-linked firms' stock returns are in top quintile and shorts the stocks whose technology-linked firms' stock returns are in the bottom quintile delivers a monthly return of $0.925 \%$ ( $t$-statistic $=4.60)$, or an annualized return of $11.1 \%$.

Controlling for common risk factors leaves the magnitude and significance of the longshort portfolio return largely unchanged. Similar to raw returns, all the alphas rise monotonically across the quintile portfolios as the technology-linked return goes from lowest in quintile 1 to highest in quintile 5 . The CAPM alpha computed using the return difference between the highest and lowest return quintile portfolios is $0.962 \%(t$-statistic $=4.85)$. The Fama and French $(1993)$ (FF3 hereafter) alpha, including market, size, and book-to-market factors, is $1.046 \%$ per month $(t$-statistic $=4.75)$, or approximately $12.6 \%$ per year. The Carhart $(1997)$ model (Carhart hereafter) including FF3 factors and the momentum factor has an alpha of $0.918 \%$ per month ( $t$ statistic $=5.21)$. Lastly, we adjust returns using a five-factor model by adding the traded liquidity factor of Pastor and Stambaugh (2003) (PS hereafter). The corresponding alpha is $0.919 \%$ per month ( $t$-statistic $=5.52)$. The results show that even after controlling for common risk factors, higher (lower) technology-linked stocks earn higher (lower) subsequent (risk-adjusted) returns.

Using value weights $(\mathrm{VW})$ rather than equal weights delivers similar results. The raw returns of VW portfolios increase monotonically from the lowest technology-linked firm return quintile to the highest technology-linked firm return quintile. The baseline technology-based 
strategy portfolio earns a monthly return of $0.401 \%(t$-statistic $=2.14)$. Controlling for common risk factors also leaves the magnitude and significance of the long-short portfolio return largely unchanged. All of the alphas increase monotonically from quintile 1 to quintile 5. The CAPM alpha is $0.435 \%(t$-statistic $=2.37)$, the FF3 alpha is $0.476 \%(t$-statistic $=2.44)$, the Carhart alpha is $0.312 \%$ ( $t$-statistic $=1.76)$, and the PS alpha is $0.365 \%$ ( $t$-statistic $=2.12)$.

Although abnormal returns are large and significant for the long-short strategy, technology-based strategy returns are asymmetric: the returns of the long-short portfolio are largely driven by slow diffusion of positive news. This pattern is in contrast to that of the customer-supplier strategy of Cohen and Frazzini (2008), in which the returns of the long-short portfolio are driven by the slow diffusion of negative news.

Table 3 presents the subsample robustness results. We separate the full sample period into four sub-periods: from January 1968 to December 1979, from January 1980 to December 1989, from January 1990 to December 1999, and from January 2000 to December 2011. In all subperiods, the alpha of EW portfolios produced by the five-factor model (Fama-French three factors, Carhart predictability factor, and Pastor and Stambaugh liquidity factor) increase monotonically from the lowest technology-linked firm return quintile to the highest technologylinked firm return quintile. For all sub-periods, the stock returns of a firm's technologically linked firms have significant predictability on the firm's future stock returns. The EW technology-based long-short portfolio delivers a monthly return of $0.985 \%(t$-statistic $=4.97)$ from January 1968 to December 1979, 0.598\% (t-statistic $=4.47)$ from January 1980 to December 1989, 0.734\% $(t$-statistic $=2.23)$ from January 1990 to December 1999, and 0.751\% $(t$-statistic $=1.68)$ from January 2000 to December 2011. Thus, our basic result holds significantly in all subsample periods. 
[Table 3 about here]

\subsection{Limited Attention and Slow Diffusion of Information}

Limited attention and slow information diffusion might explain why the stock returns of a firm's technology-linked firms can predict the firm's future stock returns. Investors are slow to react to the positive news about a firm's technology-linked firms, and thus the firm's current stock price is too low, allowing for a subsequently higher return. Thus, high future returns of a firm's stock accord with a slow reaction of the stock market to the higher stock returns of the firm's technology-linked firms.

To verify the slow information diffusion explanation of our results, we provide several pieces of evidence. In particular, we investigate how the different levels of limited attention affect the magnitude and significance of the predictability of a firm's technology-linked firm stock return on its future stock returns. We also examine the predictive power of the technologically related firm stock returns in various subsamples sorted according to firm size, institutional ownership, and the number of analysts following.

[Table 4 about here]

In Table 4, we investigate the hypothesis that, if the information about linked firms is simultaneously collected, the return predictability of the technology-linked stock returns on a firm's future stock return should be lower compared to the case in which the information about linked firms is not simultaneously collected.

Following Cohen and Frazzini (2008), we use “common ownership” as the proxy. For each month, we extract information from quarterly mutual fund holdings in the CDA/Spectrum mutual funds database on mutual fund holdings to compute common ownership as the ratio of the number of mutual funds holding both the firm and its technology-linked firms to the number 
of mutual funds holding only the technologically related firms. This proxy measures the fraction of all mutual funds owning the technology-linked firms that also own this specific firm. The idea behind this proxy is that mutual fund managers holding both securities in their portfolios are more likely to gather information or monitor more closely both the firm and its technologylinked firms. Thus, with this common ownership, we expect information about a firm's technologically related firms to be reflected in its own prices more quickly.

In each calendar month, we first sort stocks into five groups based on the measure of common ownership. We then apply technology-based strategy separately for each of the five groups. The performances of technology-based long-short portfolio returns from this double sorting analysis are reported in Table 4.

Consistent with the technology-based long-short portfolio returns being driven by investors' limited attention, different degrees of attention, as measured by the proxy of common ownership, significantly varies the returns to the technology-based strategy. Looking at the subsample of stocks with the lowest overlap of common mutual fund managers, the EW technology-based long-short portfolio return delivers $1.196 \%$ per month $(t$-statistic $=4.04)$, while the same zero-cost portfolio for securities with the highest level of common ownership generates $0.657 \%$ per month $(t$-statistic $=2.57)$. The spread in common ownership generates a significant spread in the returns to the technology-based strategy of $0.539 \%$ per month.

[Table 5 about here]

Table 5 reports the average returns of our technology-based portfolio strategy in various subsamples ranked by the alternative proxy of limited attention. We investigate how the abnormal returns from the technology-based long-short portfolio vary across firms with different market capitalization, institutional ownership, and the number of analysts following. We expect 
that firms with smaller market capitalization, lower institution ownership, and a smaller number of analysts following produce lower abnormal return, because these firms are more likely to receive limited attention from investors.

In Panel A of Table 5, we investigate how the return predictability of the technology-based long-short portfolio depends on market capitalization. In each calendar month, we first sort stocks into five groups based on the market capitalization and then perform the technology-based strategy in each of five groups. We find that the technology-based long-short portfolio returns vary significantly across different size groups. The returns of the technology-based long-short portfolio are significantly higher for small stocks than for large stocks. Looking at the subsample of stocks with the lowest market capitalization, the EW technology-based long-short portfolio return delivers $1.182 \%$ per month $(t$-statistic $=4.90)$, while the same zero-cost portfolio for securities with the highest market capitalization generates $0.534 \%$ per month $(t$-statistic $=3.33)$. The spread in market capitalization generates a significant spread in the returns to the technology-based strategy of $0.648 \%$ per month $(t$-statistic $=2.24)$.

In Panel B of Table 5, we investigate how the return predictability of the technology-based long-short portfolio depends on institutional ownership. In each calendar month, we first sort stocks into five groups based on the degree of the institutional ownership and then perform the technology-based strategy in each of five groups. We find that the technology-based long-short portfolio returns vary significantly across different institutional ownership groups. Prices of the firms with lower institutional ownership underreact significantly more to news about technologically related firms than those with higher institutional ownership. The subsample of stocks with the lowest institutional ownership indicates that the EW technology-based long-short portfolio return delivers $1.524 \%$ per month $(t$-statistic $=5.05)$, while the same zero-cost portfolio 
for securities with a highest institutional ownership generates $0.516 \%$ per month $(t$-statistic $=$ 2.40). The spread in institutional ownership generates a significant spread in the returns to the technology-based strategy of $1.008 \%$ per month $(t$-statistic $=2.72)$.

Panel C repeats the analysis of Panel B with the proxy of limited attention as the number of analysts following. We also find that the technology-based long-short portfolio returns vary significantly across different analyst following groups. Prices of the firms with a lower number of analysts following underreact significantly more to news about technologically related firms than those with the higher number of analyst following. Looking at the subsample of stocks with the lowest number of analysts following, the EW technology-based long-short portfolio return delivers $1.439 \%$ per month $(t$-statistic $=4.34)$, while the same zero-cost portfolio for securities with a highest institutional ownership generates $0.722 \%$ per month $(t$-statistic $=2.93)$. The spread in the number of analysts following generates a significant spread in the returns to the technology-based strategy of $0.717 \%$ per month $(t$-statistic $=1.74)$.

In summary, Table 5 shows that the profitability of the technology-based strategy holds more significantly, both in magnitude and in statistical significance among firms receiving less investor attention, such as those with small capitalization, low institutional ownership, and low analyst coverage. These results are consistent with low investor attention leading to slow information diffusion, which precludes the useful information contained in the technology-linked firms from being incorporated into current stock prices. The profits of our portfolio strategy can be viewed as rewards to smart investors who pay attention to the information content of the technology-linked firms. Our portfolio strategy does earn significant profits but to a lesser degree among high attention stocks. Thus, the slow diffusion of information from the technologically related firms to the own firm occurs more prominently for stocks with low investor attention. 


\subsection{Fama-MacBeth Regression}

In this section, we use the Fama and MacBeth (1973) cross-sectional forecasting regression method to demonstrate the return predictability due to technology links by controlling a series of variables known to forecast the cross-section of returns. The dependent variable is a firm's stock

return in month $t$. The independent variables of interest are the technology-proximity-weighted portfolio return in month $t-1(t-2, t-3)$ and the cumulative return from $t-6$ to $t-1, T P W R E T_{t-1}$ (TPWRET $T_{t-2,}$ TPWRET $\left.T_{t-3}\right)$ and TPWRET $T_{t-1, t-6 .}$ These technology-proximity-weighted portfolios include all technology-linked firms. An alternative independent variable of interest is the firm's corresponding EW portfolio return in month $t-1, E W R E T_{t-1}$, which is the average return of the equal-weighted portfolio. We control for a number of firm characteristics, including firm size as measured by the logarithm of the market capitalization at the end of month $t-1$ ( $\ln M E$ ), the logarithm of the book-to-market ratio $(\ln (B E / M E))$, the firm's month $t-1$ return $\left(R E T_{t-1}\right)$ to control for the short-term reversal effect (Jegadeesh (1990)), and the firm's own past sevenmonth return, not including the month $t-1$ return $\left(R E T_{t-2, t-7)}\right.$ to control for price momentum effect (Jegadeesh and Titman (1993)). We report the time-series averages of cross-sectional regression coefficients and the associated $t$-statistics using the Newey-West (1987) standard errors.

\section{[Table 6 about here]}

The results in Table 6 tell a consistent story: the past technology-linked portfolio return forecasts a firm's future stock returns. The effect is economically and statistically significant, after controlling for the set of variables known to forecast the cross-section of returns. Column (1) of Table 6 presents the basic regression results for stocks with technology-linked firms. The coefficient estimate for TPWRET $\mathrm{T}_{\mathrm{t}-1}$ is significantly positive. Its value of 0.049 implies that a one 
standard deviation increase in TPWRET $_{\mathrm{t}-1}(=6.81 \%)$ would increase the firm's risk-adjusted monthly return on average by 33 basis points. Column (2) shows that, controlling for the firm characteristics, the coefficient on TPWRET $_{\mathrm{t}-1}$ is still significantly positive 0.065 (t-statistic $=$ 8.18). In Columns (3), (4), and (5), we control for TPWRET $T_{t-2}$, TPWRET $_{t-3,}$ EWRET $_{t-1}$ and

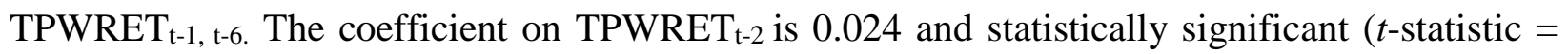
2.93) and that on $\operatorname{TPWRET}_{\mathrm{t}-3}$ is 0.016 and is also statistically significant ( $t$-statistic $=2.12$ ), suggesting that the impact of the lagged partners' return lasts for three months. Instead of weighting the stock returns of technology-linked firms by technology proximity, Column (4) uses the equal-weighted average return of technology-linked firms in month t-1. The coefficient on EWRETt-1 is statistically significant and equal to 0.066 ( $t$-statistic $=8.34)$. The coefficient estimate on TPWRET $\mathrm{T}_{\mathrm{t}-1, \mathrm{t}-6}$ of $0.022(t$-statistic $=6.50)$ suggests that the stock return predictability of technological links exists for the cumulative stock returns of technology-linked firms over the past six months.

In all models of Table 6, all characteristics except for the firm's own past six-month return from month $t-7$ to $t-2$ are significant. The size coefficient is significantly negative, indicating a negative relation between size in month $t-1$ and return in $t$. The $\ln (\mathrm{BE} / \mathrm{ME})$ coefficient is significantly positive, indicating a positive relation between $\mathrm{B} / \mathrm{M}$ in month $\mathrm{t}-1$ and the return in $\mathrm{t}$. Both are consistent with the findings in Fama and French (1992), Fama and French (1993), and Fama and French (1996). The $R E T_{t-1}$ coefficient is negative, indicating a negative relation between returns in months $t-1$ and $t$, consistent with the findings in Jegadeesh (1990) and Lehmann (1990).

[Table 7 about here] 
Table 7 augments the tests of Table 6 to control for the two industry predictability effects. The first one is the industry predictability effect of Moskowitz and Grinblatt (1999), which shows that the momentum effect is more prominent on the industry level than on the firm level. To control for this industry predictability effect, we use the following variables: VWRET_FF48 ${ }_{1}$ (Column (1)), the value-weighted return of FF 48 portfolios in month $t-1$, where the portfolio includes all firms in the same FF 48 industry, EWRET_FF12_P1 $1_{t-1}$ (Column (4)); the equalweighted return of the top 30\% market capitalization stocks in the firm's FF 12 industries in month $t-1, E W R E T \_F F 12 \_P 2 t-1$ (Column (4)); the equal-weighted return of the middle $40 \%$ market capitalization stocks in the firm's FF 12 industries in month $t-1$, and EWRET_FF12_P3 $t_{-1}$ (Column (4)); and the equal-weighted return of the bottom 30\% market capitalization stocks in the firm's FF 12 industries in month $t-1$.

The second industry effect of interest is the cross-industry predictability effect of Menzly and Ozbas (2006), which shows that stocks that are in the supplier and customer industries crosspredict each other's returns. To control for the cross-industry predictability effect, we use the

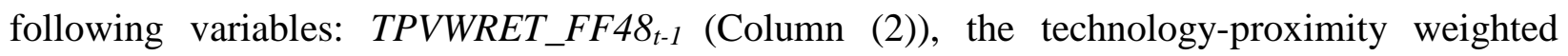
returns of the FF 48 value-weighted portfolio in month $t-1$; TPEWRET_FF12_P1 $1_{t-1}$ (Column (5)), the technology-proximity weighted returns of the equal-weighted return of the top $30 \%$ market capitalization stocks in the technology-linked firm's FF 12 industries in month $t$ 1;TPEWRET_FF12_P2 $2_{t-1}$ (Column (5)), the technology-proximity weighted returns of the equalweighted return of the middle $40 \%$ market capitalization stocks in the technology-linked firm's FF 12 industries in month $t-1$; and TPEWRET_FF12_P3 ${ }_{t-1}$ (Column (5)), the technologyproximity weighted returns of the equal-weighted return of the bottom $30 \%$ market capitalization stocks in the technology-linked firm's FF 12 industries in month t-1. In Column (6), we control 
for the two industry predictability effects simultaneously. In Column (7), we control for both the industry predictability effects and all the firm characteristics simultaneously. We then report the time-series averages of cross-sectional regression coefficients and the associated $t$-statistics using the Newey-West (1987) standard errors.

All models show that the past technology-linked portfolio return significantly and positively forecasts a firm's future stock returns in the presence of the industry and crossindustry predictability effects. Column (1) of Table 7 shows that, upon controlling for VWRET_FF48 $8_{t-1}$, which is the proxy for the industry predictability effect, the coefficient estimate for TPWRET $T_{t-1}$ is significantly positive and equal to 0.055 ( $t$-statistic $=7.19$ ). Column (2) shows that, controlling for TPVWRET_FF48 $8_{t-1}$, the proxy for the cross-industry predictability effect, the coefficient estimate for $T P W R E T_{t-1}$, is significantly positive and equal to 0.050 ( $t$-statistic $\left.=6.66\right)$. Column (3) controls for both the industry predictability effect and the cross-industry predictability effect, and the coefficient estimate for $T P W R E T_{t-1}$ is still significantly positive and equal to 0.049 ( $t$-statistic $=6.41)$. Columns (4), (5), and (6) repeat the analysis of Columns (1), (2), and (3), replacing VWRET_FF48 $8_{t-1}$ with EWRET_FF12_P1 $1_{t-1}, E W R E T \_F F 12_{-} P 2_{t-1}$, and EWRET_FF12_P3 $3_{t-1}$, and replacing TPVWRET_FF48 $8_{t-1}$ with TPEWRET_FF12_P1 $1_{t-1}$, TPEWRET_FF12_P2 ${ }_{t-1}$, and TPEWRET_FF12_P3 $3_{t-1}$. The coefficient estimate for TPWRET $T_{t-1}$ is significantly positive for all models: $0.054(t$-statistic $=7.76)($ Column $(5)), 0.051(t$-statistic $=$ 7.28) $($ Column (6)) and 0.050 (t-statistic $=7.10)($ Column (6)). In Column (7), we perform an expansive analysis with all of the variables separately included above and the result does not change: the coefficient estimate for TPWRET $T_{t-1}$ is significantly positive and equal to 0.043 (tstatistic $=6.02$ ). 
In all models of Table 7, all characteristics except for the firm's own six-month cumulative return from month $t-7$ to $t-2$ are significant, and the signs are the same as those of Table 6: the smaller and high B/M firms have higher future returns, consistent with the findings in Fama and French (1992), Fama and French (1993), and Fama and French (1996). There also exists a shortterm reversal effect, consistent with the findings in Jegadeesh (1990) and Lehmann (1990).

\subsection{Other Economic Linkages}

In this section, we perform further robustness tests on various subsamples. We show that, in the subsamples with different specifications, the relationship between the technology-linked portfolio return and the firm's own future stock returns holds strongly.

[Table 8 about here]

Table 8 shows that the positive and significant relation between the technology-linked portfolio return and the firm's own future stock returns is not driven by the return predictability between firms with other types of economic linkages. In the first row, we exclude the technology related firms in the same FF-48 industry category. The raw returns of EW portfolios increase monotonically from the lowest technology-linked return quintile to the highest technology-linked return quintile. The EW technology-based strategy with long stocks in the top quintile and short stocks in the bottom quintile delivers a monthly return of $0.703 \%$ ( $t$-statistic $=5.34)$. In the second row, we exclude the technologically related firms in the same FF-12 industry category. The EW technology-based strategy generates a monthly return of $0.530 \%(t$-statistic $=4.56)$. In the third row, we exclude the technologically related firms that are in strategic alliances with the firms in the portfolio. The EW technology-based strategy generates a monthly return of $0.982 \%$ $(t$-statistic $=3.35)$. In the fourth row, we exclude the technologically related firms that are principal customers of the firms or reported as principal customers by the firms. The EW 
technology-based strategy generates a monthly return of $0.909 \%$ ( $t$-statistic $=4.12)$. In the fifth row, we exclude the technologically related firms in the same FF-48 industry, in strategic alliances, or in customer/supplier relationships. The EW technology-based strategy generates a monthly return of $0.798 \%(t$-statistic $=3.78)$. In the sixth row, we exclude the technologically related firms in the same FF-12 industry, in strategic alliances, or in customer/supplier relationships. The EW technology-based strategy generates a monthly return of $0.530 \%$ ( $t$ statistic $=3.14)$. Table 8 shows that technology predictability is not driven by other types of economic linkages between firms.

\subsection{Technology Diversity}

Table 9 controls for the technology diversity as defined in Hirshleifer, Hsu, and Li (2013) as patents or citations scaled by research and development expenditures. The technology diversity is a proxy for the complexity of a firm's innovative activities. For each firm and patent class, we calculate the ratio of the firm's number of patent applications from $t-3$ to $t-1$ in that patent class to the total number of patent applications in the same period. The firm's technology diversity at time $t$ is one minus the Herfindahl-Hirschman index of the ratio across all patent classes:

$$
\text { Technology Diversity }=1-\sum_{k=1}^{K}\left(\frac{n_{k}}{\sum_{k=1}^{K} n_{k}}\right)^{2} \text {, }
$$

where $n_{k}$ is the number of patents applied in the patent class $k$ during the period $t-2$ to $t$, and $K$ is the total number of patent classes.

[Table 9 about here]

Panel A of Table 9 performs a double sort. In each calendar month, we first place stocks into three groups based on the technology diversity, then perform the technology-based strategy 
in each of three groups. We find that the technology-based long-short portfolio returns are positive and significant across all groups. The EW technology-based long-short portfolio return of the lowest technology diversity group delivers $0.500 \%$ per month $(t$-statistic $=4.51$ ), while the same zero-cost portfolio for securities of the highest technology diversity group generates $0.753 \%$ per month $(t$-statistic $=4.69)$. The results suggest that the predictability is stronger for highly technologically diversified firms. This indicates that limited attention is more severe among more technologically complex firms.

Panel B of Table 9 confirms the findings of Panel A with the Fama-MacBeth regression. The dependent variable is this month's return of a firm. In Column (1), the independent variables are the technology-proximity-weighted portfolio returns in month t- 1 of the five quintiles. In Column (2), the independent variables are the technology-proximity-weighted portfolio returns in month t-1 of the tercile portfolios sorted by technology diversity. In Column (3), in addition to the independent variables in Column (2), we also add the returns of the EW tercile portfolios of the technologically related firms in the same FF-12 industry and add the technology-proximity tercile portfolios of the technologically related firms in the same FF-12 industry. The results show that the predictability is indeed more pronounced for highly technologically diversified firms. The coefficients on the technology-proximity-weighted portfolio returns in month t-1 of the tercile portfolios sorted by technology diversity are monotonically increasing for Columns (2) and (3) and are all statistically significant. In Column (2), from the lowest tercile to the highest tercile of technology diversity, the coefficients on the technology-proximity-weighted portfolio returns in month t-1 are $0.015(t$-statistic $=4.48), 0.025(t$-statistic $=5.38)$, and $0.036(t$-statistic $=$ 5.10), respectively. In Column (3), from the lowest tercile to the highest tercile of technology diversity, the coefficients on the technology-proximity-weighted portfolio returns in month t-1 
are $0.012(t$-statistic $=3.92), 0.015(t$-statistic $=3.42)$, and $0.022(t$-statistic $=3.32)$. In all three models of Table 9, all of the characteristics except for the firm's own past seven-month return, not including the last month's return, are significant, and the signs are the same as those of Tables 6 and 7.

\subsection{Real Performance}

Table 10 examines whether technologically related firms are correlated in operational performance. The dependent variable is the firm level's ROA. The independent variables are the assets-weighted average ROA of all firms and the assets-weighted average ROA of the technologically related firms. Column (1) uses all technologically related firms. Columns (2) and (3) exclude the firms in the same FF-48 and FF12 industry categories, respectively. Columns (4) and (5) exclude the firms in strategic alliances and customer-supplier relationships, respectively. Columns (5) and (6) exclude the firms in the same FF-48/12 and strategic alliances and customer-supplier relationships. The coefficients on the average ROA of the technologically related firms are all positive and significant for all models. The results show that technologically related firms are correlated in real performance.

\section{[Table 10 about here]}

\section{Conclusion}

This paper uncovers an important information linkage in stock returns, namely the technological relatedness between firms. The information on technology relatedness is publicly available. Investors, however, fail to take these links into account, resulting in predictable returns. A long-short equity trading strategy sorted on lagged returns of technology-linked firms yield monthly alphas of around 105 basis points. This technology predictability strategy is largely unaffected in both magnitude and significance by controlling for the three-factor model, 
liquidity, own-firm predictability, industry predictability, within-industry lead-lag relationships, and cross-industry predictability. Furthermore, alternative proxies for investors' attention, such as firm size, institutional holding, and the number of analysts following, also strongly impact the technology-based trading strategy returns. Thus, investors' limited attention could be the source of the violations of semi-strong form efficiency based on a trading strategy designed to exploit the information contained in the returns of technologically related firms. 


\section{References}

Addoum, Jawad M., Alok Kumar, and Kelvin Law, Geographic diffusion of information and stock returns, Working Paper, University of Miami (2014).

Ball, Richard E., The impact of technology on economic growth, American Journal of Economics and Sociology, 16 (1957), 281-290.

Barber, Brad, and Terrance Odean, All that glitters: The effect of attention and news on the buying behavior of individual and institutional investors, Review of Financial Studies, 21 (2006), 785-818.

Bena, Jan, and Kai Li, Corporate innovations and mergers and acquisitions, Journal of Finance, 69 (2014), 1923-1960.

Bloom, Nick, Mark Schankerman, and John Van Reenen, Identifying technology spillovers and product market iivalry, Econometrics, 81 (2013), 1347-1393.

Cao, Jie, Tarun Chordia, and Chen Lin, Alliances and return predictability, Journal of Financial and Quantitative Analysis, 51 (2015), 1689-1717.

Cohen, Lauren, and Frazzini, Andrea, Economic links and predictable returns, Journal of Finance, 63 (2008), 1977-2011.

Cohen, Lauren, and Dong Liu, Complicated firms, Journal of Financial Economics, 104 (2012), 383-400.

Fama, Eugene F., and Kenneth R. French, The cross-section of expected stock returns, Journal of Finance, 47 (1992), 427-465.

Fama, Eugene F., and Kenneth R. French, Common risk factors in the returns on stocks and bonds, Journal of Financial Economics, 33 (1993), 3-56.

Fama, Eugene F., and Kenneth R. French, Multifactor explanations of asset pricing anomalies, Journal of Finance, 51 (1996), 55-84. 
Fama, Eugene F., and James D. MacBeth, Risk, return, and equilibrium: empirical tests, Journal of Political Economy, 81 (1973), 607-636.

Garleanu, Nicolae ,Stavros Panageas, and Jianfeng Yu, Technological Growth and Asset Pricing, Journal of Finance, 67 (2012), 1265-1292

Gomes, Joao, Leonid Kogan, and Lu Zhang, Equilibrium cross section of returns. Journal of Political Economy, 111, (2003), 693-732

Hirshleifer, David, and Siew Hong Teoh, Limited attention, information disclosure, and financial reporting, Journal of Accounting and Economics, 36 (2003), 337-386.

Hirshleifer, David, Po-Hsuan Hsu, and Dongmei Li, Innovative efficiency and stock returns, Journal of Financial Economics, 107 (2013), 632-654.

Hirshleifer, David, Po-Husan Hsu, and Dongmei Li, Innovative originality, profitability, and stock returns, Review of Financial Studies, (2017), forthcoming.

Hong, Harrison, and Jeremy Stein, A unified theory of underreaction, predictability trading, and overreaction in asset markets, Journal of Finance, 54 (1999), 2143-2184.

Hou, Kewei, Industry information diffusion and the lead-lag effect in stock returns, Review of Financial Studies, 20 (2006), 1113-1138.

Hou, Kewei, and Tobias Moskowitz, Market frictions, price delay, and the cross-section of expected returns, Review of Financial Studies, 18 (2005), 981-1020.

Hou, Kewei, Lin Peng, and Wei Xiong, A tale of two anomalies: The implication of investor attention for price and earnings predictability, Working Paper, Baruch College, Ohio State University, and Princeton University (2006).

Huberman, Gur, Familiarity breeds investment, Review of Financial Studies, 14 (2001), 659680. 
Huberman, Gur, and Tomer Regev, Contagious speculation and a cure for cancer: A non-event that made stock prices soar, Journal of Finance, 56 (2001), 387-396.

Hsu, Po-Hsuan, Technological innovations and aggregate risk premiums. Journal of Financial Economics, 94 (2009), 264-79.

Jaffe, Adam B., Technological opportunity and spillovers of R\&D: Evidence from firms’ patents, profits, and market value, American Economic Review, 76 (1986), 984-1001.

Jaffe A, M. Trajtenberg, and M. Fogarty, Knowledge Spillovers and Patent Citations: Evidence from a Survey of Inventors. American Economic Review, 90 (2000), 215-218.

Jaffe A, M. Trajtenberg, and R. Henderson, Geographic localization of knowledge spillovers as evidenced by patent citations. the Quarterly journal of Economics, 108 (1993), 577-598.

Jegadeesh, Narasimhan, Evidence of predictable behavior of security returns, Journal of Finance, 45 (1990), 881-898.

Kogan, Leonid, Dimitris Papanikolaou, Amit Seru, and Noah Stoffman, Technological innovation, resource allocation, and growth, Quarterly Journal of Economics, (2017), Forthcoming.

Kahneman, Daniel, 1973, Attention and effort (Prentice Hall, New Jersey).

Kumar, Praveen and Dongmei Li, Capital investment, innovative capacity, and stock returns, Journal of Finance ,71 (2016), 2059-2094.

Lehmann, Bruce N., Fads, Martingales, and market efficiency, Quarterly Journal of Economics, 105 (1990), 1-28.

Leary, Mark T., and Michael R. Roberts, 2014, Do peer firms affect corporate financial policy? Journal of Finance 69, 139-178.

Li, Kai, Jiaping Qiu and Jin Wang, Technology Conglomeration, Strategic Alliances, and Corporate Innovation, Management Science, forthcoming. 
Liu, Binying, Network centrality and gradual information Diffusion, Working Paper, Northwestern University (2015).

Lo, Andrew, and A. Craig MacKinlay, When are contrarian profits due to stock market overreaction? Review of Financial Studies, 3 (1990), 175-205.

Menzly, L., and O. Ozbas. Market segmentation and cross-predictability of Returns, Journal of Finance, 65 (2010), 1555-1580.

Merton, Robert. C. A simple model of capital market equilibrium with Incomplete Information, Journal of Finance, 42 (1987), 483-510.

Moskowitz, T. J., and M. Grinblatt. Do industries explain predictability? Journal of Finance, 54 (1999), 1249-1290.

Newey, Whitney K., and Kenneth D. West. A simple, positive semi-definite, heteroskedasticity and autocorrelation consistent covariance matrix, Econometrica, 55 (1987), 703-708.

Pastor, Lubos, and Robert Stambaugh, Liquidity risk and expected stock returns, 2003, Journal of Political Economy, 111 (2003), 642-685.

Pástor, L’uboš, and Pietro Veronesi. 2009. "Technological Revolutions and Stock Prices." American Economic Review,Peng, Lin, and Wei Xiong, Investor attention, overconfidence, and category learning, Journal of Financial Economics, 80 (2006), 563-602.

Qiu, Jiaping, and Chi Wan, 2015, Technology spillovers and corporate cash holdings, Journal of Financial Economics 115, 558-573.

Smith, Adam, 1904, An inquiry into the nature and causes of the wealth of nations (Edwin Cannan, ed.). 
Solow, Robert M., A contribution to the theory of economic growth, Quarterly Journal of Economics, 70 (1956), 65-94.

Trajtenberg M., A Penny for Your Quotes: Patent Citations and the Value of Innovations. The RAND Journal of Economics, 21 (1990), 172-187. 
Table 1

\section{Summary statistics}

This table reports the average number of technology-linked firms and average technology proximity over time. Following Jaffe (1986), we define the technological proximity as a correlation coefficient:

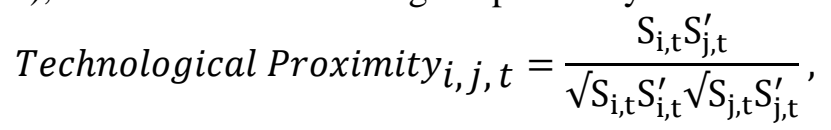

where the vector $S_{i, t}=\left(s_{i, 1, t}, \ldots, s_{i, k, t}, \ldots, s_{i, K, t}\right)$ captures the scope of innovation activity through patent output of firm $i$, and the vector $S_{j, t}=\left(s_{j, 1, t}, \ldots, s_{j, k, t}, \ldots, s_{j, K, t}\right)$ captures the scope of innovation activity through patent output of firm $j$. The subscript $k$ in $(1, . . K)$ is the technology class index. The scalar $s_{i, k, t}\left(s_{j, k, t}\right)$ is the ratio of the number of awarded patents to firm $i(j)$ in technology class $k$ with award years from t-3 to $t-1$ to the total number of awarded patents to firm $i(j)$ awarded over the same period. Our patent data cover the period between 1968 and 2011 (528 months).

\begin{tabular}{|c|c|c|c|c|c|c|}
\hline Year & \# of firms & $\begin{array}{l}\text { Avg \# of } \\
\text { related firms }\end{array}$ & $\begin{array}{l}\text { Avg tech } \\
\text { proximity }\end{array}$ & $\begin{array}{l}\% \text { of related } \\
\text { firms in the } \\
\text { same FF } 48 \\
\text { industry }\end{array}$ & $\begin{array}{c}\text { Avg tech } \\
\text { proximity if } \\
\text { same FF } 48 \\
\text { industry } \\
\end{array}$ & $\begin{array}{l}\text { Avg tech } \\
\text { proximity if } \\
\text { different FF } \\
48 \text { industry }\end{array}$ \\
\hline 1968 & 627 & 53 & 0.29 & $15.69 \%$ & 0.35 & 0.27 \\
\hline 1969 & 659 & 54 & 0.29 & $15.57 \%$ & 0.34 & 0.28 \\
\hline 1970 & 717 & 60 & 0.30 & $16.60 \%$ & 0.36 & 0.28 \\
\hline 1971 & 753 & 62 & 0.31 & $16.96 \%$ & 0.36 & 0.29 \\
\hline 1972 & 786 & 65 & 0.30 & $15.81 \%$ & 0.35 & 0.29 \\
\hline 1973 & 845 & 66 & 0.31 & $14.84 \%$ & 0.35 & 0.29 \\
\hline 1974 & 864 & 67 & 0.29 & $14.58 \%$ & 0.35 & 0.28 \\
\hline 1975 & 881 & 65 & 0.30 & $15.07 \%$ & 0.35 & 0.29 \\
\hline 1976 & 1,176 & 63 & 0.33 & $13.78 \%$ & 0.37 & 0.32 \\
\hline 1977 & 1,252 & 65 & 0.34 & $13.43 \%$ & 0.37 & 0.33 \\
\hline 1978 & 1,271 & 62 & 0.34 & $13.39 \%$ & 0.37 & 0.33 \\
\hline 1979 & 1,226 & 58 & 0.35 & $13.58 \%$ & 0.38 & 0.34 \\
\hline 1980 & 1,138 & 52 & 0.36 & $14.89 \%$ & 0.39 & 0.35 \\
\hline 1981 & 1,107 & 50 & 0.36 & $14.98 \%$ & 0.39 & 0.35 \\
\hline 1982 & 1,069 & 47 & 0.37 & $15.75 \%$ & 0.40 & 0.36 \\
\hline 1983 & 1,031 & 48 & 0.36 & $14.89 \%$ & 0.39 & 0.35 \\
\hline 1984 & 1,042 & 45 & 0.37 & $15.48 \%$ & 0.39 & 0.36 \\
\hline 1985 & 1,059 & 43 & 0.38 & $15.55 \%$ & 0.39 & 0.36 \\
\hline 1986 & 1,034 & 43 & 0.37 & $16.05 \%$ & 0.40 & 0.36 \\
\hline 1987 & 1,069 & 42 & 0.39 & $16.10 \%$ & 0.42 & 0.37 \\
\hline 1988 & 1,111 & 42 & 0.40 & $18.11 \%$ & 0.42 & 0.38 \\
\hline 1989 & 1,076 & 40 & 0.40 & $19.54 \%$ & 0.43 & 0.39 \\
\hline 1990 & 1,087 & 42 & 0.41 & $20.05 \%$ & 0.44 & 0.39 \\
\hline 1991 & 1,087 & 43 & 0.41 & $20.57 \%$ & 0.44 & 0.40 \\
\hline 1992 & 1,106 & 43 & 0.43 & $20.88 \%$ & 0.45 & 0.41 \\
\hline 1993 & 1,125 & 43 & 0.42 & $21.11 \%$ & 0.45 & 0.40 \\
\hline 1994 & 1,125 & 42 & 0.41 & $22.47 \%$ & 0.44 & 0.39 \\
\hline 1995 & 1,159 & 42 & 0.42 & $23.42 \%$ & 0.45 & 0.40 \\
\hline
\end{tabular}




\begin{tabular}{ccccccc}
1996 & 1,234 & 43 & 0.44 & $25.30 \%$ & 0.48 & 0.41 \\
1997 & 1,314 & 44 & 0.45 & $26.20 \%$ & 0.48 & 0.43 \\
1998 & 1,367 & 44 & 0.48 & $27.59 \%$ & 0.51 & 0.46 \\
1999 & 1,420 & 44 & 0.49 & $27.65 \%$ & 0.52 & 0.46 \\
2000 & 1,429 & 46 & 0.50 & $29.72 \%$ & 0.53 & 0.47 \\
2001 & 1,404 & 48 & 0.50 & $31.65 \%$ & 0.53 & 0.48 \\
2002 & 1,352 & 48 & 0.51 & $32.94 \%$ & 0.53 & 0.48 \\
2003 & 1,346 & 48 & 0.50 & $33.33 \%$ & 0.53 & 0.48 \\
2004 & 1,441 & 53 & 0.52 & $34.78 \%$ & 0.55 & 0.50 \\
2005 & 1,427 & 56 & 0.52 & $34.56 \%$ & 0.55 & 0.49 \\
2006 & 1,368 & 55 & 0.51 & $34.71 \%$ & 0.54 & 0.48 \\
2007 & 1,300 & 56 & 0.50 & $35.52 \%$ & 0.53 & 0.46 \\
2008 & 1,225 & 52 & 0.51 & $35.10 \%$ & 0.54 & 0.48 \\
2009 & 1,133 & 49 & 0.52 & $35.73 \%$ & 0.54 & 0.49 \\
2010 & 1,137 & 48 & 0.52 & $36.55 \%$ & 0.54 & 0.50 \\
2011 & 1,106 & 45 & 0.55 & $38.08 \%$ & 0.57 & 0.53 \\
Average & 1,125 & 51 & 0.41 & $22.47 \%$ & 0.44 & 0.39 \\
\hline
\end{tabular}


Table 2

Technology-Based Strategy, Abnormal Returns 1968-2011

This table reports the calendar-time portfolio abnormal returns. At the beginning of every calendar month, stocks are ranked in ascending order by the average return of its technology-linked firms at the end of the previous month. The ranked stocks are assigned to one of five quintile portfolios. All stocks are equal (value) weighted within a given portfolio, and the portfolios are rebalanced every calendar month to maintain equal (value) weights. This table includes all available stocks with stock price greater than $\$ 1$ at portfolio formation. Alpha is the intercept on a regression of monthly excess return from the rolling strategy. The explanatory variables are the monthly returns from the CAPM factor, the Fama and French (1993) factors, the Carhart (1997) predictability factor, and the Pastor and Stambaugh (2003) liquidity factor. $\mathrm{H}-\mathrm{L}$ is the alpha of a zero-cost portfolio that holds the top quintile technology-linked stocks and sells short the bottom quintile technology-linked return stocks. Returns and alphas are in monthly percent, $t$-statistics are shown below the coefficient estimates, and 1\% (5\% and 10\%) statistical significance is indicated by $* * *(* *$ and $*)$.

\begin{tabular}{|c|c|c|c|c|c|c|}
\hline & \multicolumn{6}{|c|}{ Panel A: Equal Weights } \\
\hline & Q1(Low) & Q2 & Q3 & Q4 & Q5(High) & $\mathrm{H}-\mathrm{L}$ \\
\hline Excess returns & $\begin{array}{l}0.366 \\
(1.18)\end{array}$ & $\begin{array}{l}0.590 * \\
(1.95)\end{array}$ & $\begin{array}{c}0.785^{* * *} \\
(2.70)\end{array}$ & $\begin{array}{c}0.991 * * * \\
(3.25)\end{array}$ & $\begin{array}{c}1.291 * * * \\
(3.82)\end{array}$ & $\begin{array}{c}0.925 * * * \\
(4.60)\end{array}$ \\
\hline CAPM alpha & $\begin{array}{l}-0.160 \\
(-1.13)\end{array}$ & $\begin{array}{l}0.085 \\
(0.69)\end{array}$ & $\begin{array}{c}0.302 * * \\
(2.26)\end{array}$ & $\begin{array}{c}0.509 * * * \\
(3.22)\end{array}$ & $\begin{array}{c}0.802 * * * \\
(4.03)\end{array}$ & $\begin{array}{c}0.962 * * * \\
(4.85)\end{array}$ \\
\hline FF alpha & $\begin{array}{c}0.335 * * * \\
(-3.07)\end{array}$ & $\begin{array}{l}-0.075 \\
(-0.94)\end{array}$ & $\begin{array}{c}0.165 * * \\
(2.09)\end{array}$ & $\begin{array}{c}0.361^{* * *} \\
(3.44)\end{array}$ & $\begin{array}{c}0.711^{* * * *} \\
(4.45)\end{array}$ & $\begin{array}{c}1.046^{* * *} \\
(4.75)\end{array}$ \\
\hline Carhart alpha & $\begin{array}{l}-0.158 \\
(-1.52)\end{array}$ & $\begin{array}{l}0.081 \\
(1.08)\end{array}$ & $\begin{array}{c}0.263^{* * *} \\
(3.32)\end{array}$ & $\begin{array}{c}0.466^{* * *} \\
(4.30)\end{array}$ & $\begin{array}{c}0.760^{* * *} \\
(5.60)\end{array}$ & $\begin{array}{c}0.918^{* * *} \\
(5.21)\end{array}$ \\
\hline \multirow[t]{3}{*}{ 5-factor alpha } & $\begin{array}{c}-0.170 * \\
(-1.67) \\
\end{array}$ & $\begin{array}{l}0.066 \\
(0.91) \\
\end{array}$ & $\begin{array}{c}0.249 * * * \\
(3.25)\end{array}$ & $\begin{array}{c}0.447 * * * \\
(4.22)\end{array}$ & $\begin{array}{c}0.749 * * * \\
(5.55)\end{array}$ & $\begin{array}{c}0.919 * * * \\
(5.52) \\
\end{array}$ \\
\hline & \multicolumn{6}{|c|}{ Panel B: Value Weights } \\
\hline & Q1(Low) & Q2 & Q3 & Q4 & Q5(High) & $\mathrm{H}-\mathrm{L}$ \\
\hline Excess returns & $\begin{array}{l}0.286 \\
(1.16)\end{array}$ & $\begin{array}{c}0.397 * \\
(1.81)\end{array}$ & $\begin{array}{l}0.401^{*} \\
(1.90)\end{array}$ & $\begin{array}{c}0.564^{* * *} \\
(2.71)\end{array}$ & $\begin{array}{c}0.688 * * * \\
(2.95)\end{array}$ & $\begin{array}{c}0.401 * * \\
(2.14)\end{array}$ \\
\hline CAPM alpha & $\begin{array}{l}-0.150 \\
(-1.35)\end{array}$ & $\begin{array}{l}-0.011 \\
(-0.15)\end{array}$ & $\begin{array}{l}0.010 \\
(0.14)\end{array}$ & $\begin{array}{c}0.178 * * \\
(2.18)\end{array}$ & $\begin{array}{c}0.285^{* *} \\
(2.52)\end{array}$ & $\begin{array}{c}0.435 * * \\
(2.37)\end{array}$ \\
\hline FF alpha & $\begin{array}{l}-0.097 \\
(-0.83)\end{array}$ & $\begin{array}{l}0.026 \\
(0.36)\end{array}$ & $\begin{array}{l}0.036 \\
(0.51)\end{array}$ & $\begin{array}{c}0.213^{* * *} \\
(2.68)\end{array}$ & $\begin{array}{c}0.378 * * * \\
(3.40)\end{array}$ & $\begin{array}{c}0.476 * * \\
(2.44)\end{array}$ \\
\hline Carhart alpha & $\begin{array}{l}0.019 \\
(0.17)\end{array}$ & $\begin{array}{l}0.009 \\
(0.12)\end{array}$ & $\begin{array}{l}0.003 \\
(0.04)\end{array}$ & $\begin{array}{c}0.205^{* * *} \\
(2.70)\end{array}$ & $\begin{array}{c}0.332 * * * \\
(2.97)\end{array}$ & $\begin{array}{c}0.312 * \\
(1.76)\end{array}$ \\
\hline 5-factor alpha & $\begin{array}{l}-0.009 \\
(-0.08) \\
\end{array}$ & $\begin{array}{l}0.010 \\
(0.14) \\
\end{array}$ & $\begin{array}{l}-0.010 \\
(-0.13) \\
\end{array}$ & $\begin{array}{c}0.203^{* * *} \\
(2.60)\end{array}$ & $\begin{array}{c}0.356^{* * *} \\
(3.18)\end{array}$ & $\begin{array}{c}0.365^{* *} \\
(2.12) \\
\end{array}$ \\
\hline
\end{tabular}


Table 3

Technology-Based Strategy, Abnormal Returns Subsample Periods

This table reports the calendar-time portfolio abnormal returns for four subsample periods. At the beginning of every calendar month, stocks are ranked in ascending order by technology proximity return at the end of the previous month. The ranked stocks are assigned to one of five quintile portfolios. All stocks are equal weighted within a given portfolio, and the portfolios are rebalanced every calendar month to maintain equal weights. This table includes all available stocks with stock price greater than $\$ 1$ at portfolio formation. Alpha is the intercept on a regression of monthly excess return from the rolling strategy. The explanatory variables are the monthly returns from the CAPM factor, the Fama and French (1993) factors, the Carhart (1997) predictability factor, and the Pastor and Stambaugh (2003) liquidity factor. $\mathrm{H}-\mathrm{L}$ is the alpha of a zero-cost portfolio that holds the top quintile technology-linked stocks and sells short the bottom quintile technology-linked return stocks. Returns and alphas are in monthly percent, $t$-statistics are shown below the coefficient estimates, and 1\% (5\% and 10\%) statistical significance is indicated by $* * *(* *$ and $*)$.

\begin{tabular}{lcccccc}
\hline & Q1(Low) & Q2 & Q3 & Q4 & Q5(High) & H-L \\
\hline \multirow{2}{*}{$1968-79$} & $-0.363^{* *}$ & -0.049 & 0.155 & $0.268^{* *}$ & $0.622^{* * *}$ & $0.985^{* * *}$ \\
& $(-2.32)$ & $(-0.38)$ & $(1.20)$ & $(2.53)$ & $(4.41)$ & $(4.97)$ \\
$1980-89$ & -0.136 & 0.081 & $0.196^{*}$ & $0.215^{* *}$ & $0.462^{* * *}$ & $0.598^{* * *}$ \\
& $(-1.06)$ & $(0.72)$ & $(1.82)$ & $(2.17)$ & $(4.52)$ & $(4.47)$ \\
$1990-99$ & 0.139 & 0.241 & $0.335^{* *}$ & $0.492^{* * *}$ & $0.873^{* * *}$ & $0.734^{* *}$ \\
& $(0.71)$ & $(1.28)$ & $(2.24)$ & $(2.74)$ & $(4.44)$ & $(2.23)$ \\
$2000-11$ & 0.018 & 0.195 & $0.377^{*}$ & $0.605^{* *}$ & $0.769^{* *}$ & $0.751^{*}$ \\
& $(0.08)$ & $(1.09)$ & $(1.85)$ & $(2.32)$ & $(2.03)$ & $(1.68)$ \\
\hline
\end{tabular}




\section{Table 4 \\ Common Ownership and Technology-Based Strategy}

This table reports the calendar-time portfolio abnormal excess returns for portfolios double-sorted by common ownership and technology proximity return. The common ownership is the ratio of the number of mutual funds holding both a firm and its technology-linked firms to the number of mutual funds holding the technologically related firms only over the same month. At the beginning of every calendar month, stocks are ranked in ascending order first by common ownership and then by technology linked return at the end of the previous month. The ranked stocks are assigned to one of 5 by 5 quintile portfolios. All stocks are equal weighted within a given portfolio, and the portfolios are rebalanced every calendar month to maintain equal weights. This table includes all available stocks with stock price greater than $\$ 1$ at portfolio formation. $\mathrm{H}-\mathrm{L}$ is the raw return of a zero-cost portfolio that holds the top quintile technology-linked stocks and sells short the bottom quintile technology-linked return stocks. Returns and are in monthly percent, $t$-statistics are shown below the coefficient estimates, and $1 \%$ (5\% and 10\%) statistical significance is indicated by $* * *(* *$ and $*)$.

\begin{tabular}{cllllll}
\hline & Q1(Low) & \multicolumn{1}{c}{ Q2 } & \multicolumn{1}{c}{ Q3 } & \multicolumn{1}{c}{ Q4 } & Q5(High) & \multicolumn{1}{c}{ H-L } \\
\hline Q1 & -0.258 & -0.005 & 0.267 & $0.712^{* * *}$ & $0.938^{* * *}$ & $1.196^{* * *}$ \\
(Lowest Com. Own.) & $(-1.19)$ & $(-0.02)$ & $(1.30)$ & $(2.83)$ & $(3.10)$ & $(4.04)$ \\
Q2 & -0.276 & 0.134 & $0.325^{* *}$ & $0.639^{* * *}$ & $0.708^{* * *}$ & $0.984^{* * *}$ \\
& $(-1.41)$ & $(0.99)$ & $(2.18)$ & $(3.68)$ & $(2.96)$ & $(3.03)$ \\
Q3 & -0.144 & 0.086 & $0.389^{* * *}$ & $0.325^{* *}$ & $0.655^{* * *}$ & $0.799^{* * *}$ \\
& $(-0.86)$ & $(0.59)$ & $(2.72)$ & $(2.11)$ & $(3.67)$ & $(2.96)$ \\
Q4 & -0.111 & $0.306^{* *}$ & $0.276^{*}$ & $0.353^{* *}$ & $0.727^{* * *}$ & $0.838^{* * *}$ \\
& $(-0.69)$ & $(2.17)$ & $(1.86)$ & $(2.46)$ & $(3.84)$ & $(3.42)$ \\
Q5 & -0.140 & -0.002 & 0.143 & $0.357^{* * *}$ & $0.517^{* * *}$ & $0.657^{* *}$ \\
(Highest Com. Own.) & $(-0.83)$ & $(-0.01)$ & $(1.22)$ & $(2.65)$ & $(2.91)$ & $(2.57)$ \\
\hline
\end{tabular}


Table 5

Size, Institutional Ownership and the Number of Analyst Following

This table reports the calendar-time portfolio abnormal excess returns for portfolios double-sorted by size (Panel A), institutional ownership (IO) (Panel B), the number of analyst following (AF) (Panel C) respectively and technology proximity return. At the beginning of every calendar month, stocks are ranked in ascending order first by size (Panel A), institutional ownership (Panel B), the number of analyst following (Panel C) respectively and then by technology linked return at the end of the previous month. The ranked stocks are assigned to one of 5 by 5 quintile portfolios. All stocks are equal weighted within a given portfolio, and the portfolios are rebalanced every calendar month to maintain equal weights. This table includes all available stocks with stock price greater than $\$ 1$ at portfolio formation. H-L is the return of a zero-cost portfolio that holds the top quintile technology-linked stocks and sells short the bottom quintile technology-linked return stocks. Returns and alphas are in monthly percent, $t$-statistics are shown below the coefficient estimates, and $1 \%(5 \%$ and $10 \%)$ statistical significance is indicated by $* * *$ (**and $*)$.

\begin{tabular}{|c|c|c|c|c|c|c|}
\hline & \multicolumn{6}{|c|}{ Panel A: Double-Sorted by Size and the Technology Proximity Return } \\
\hline & Q1(Low) & Q2 & Q3 & Q4 & Q5(High) & $\mathrm{H}-\mathrm{L}$ \\
\hline $\mathrm{Q} 1$ & -0.069 & $0.428^{* *}$ & $0.624^{* * *}$ & $0.883 * * *$ & $1.112 * * *$ & $1.182 * * *$ \\
\hline (Smallest Size) & $(-0.40)$ & $(2.13)$ & $(3.37)$ & $(4.10)$ & $(4.53)$ & $(4.90)$ \\
\hline \multirow[t]{2}{*}{ Q2 } & $-0.319 * *$ & 0.058 & $0.315^{* *}$ & $0.282 *$ & $0.765 * * *$ & $1.084 * * *$ \\
\hline & $(-2.07)$ & $(0.47)$ & $(2.54)$ & $(1.80)$ & (3.75) & $(4.22)$ \\
\hline \multirow[t]{2}{*}{ Q3 } & $-0.247 *$ & -0.093 & $0.211^{*}$ & $0.247^{*}$ & $0.778 * * *$ & $1.025^{* * *}$ \\
\hline & $(-1.86)$ & $(-0.77)$ & (1.68) & (1.85) & $(4.60)$ & $(4.51)$ \\
\hline \multirow[t]{2}{*}{ Q4 } & -0.035 & 0.150 & $0.174^{*}$ & $0.354 * * *$ & $0.421 * * *$ & $0.456 * * *$ \\
\hline & $(-0.26)$ & $(1.42)$ & $(1.80)$ & (3.42) & (3.35) & (2.64) \\
\hline \multirow{4}{*}{$\begin{array}{c}\text { Q5 } \\
\text { (Largest Size) } \\
\end{array}$} & -0.106 & 0.021 & 0.030 & $0.291^{* * *}$ & $0.428 * * *$ & $0.534 * * *$ \\
\hline & $(-0.98)$ & $(0.28)$ & $(0.38)$ & (3.56) & (4.24) & $(3.33)$ \\
\hline & \multicolumn{6}{|c|}{ Panel B: Double-Sorted by IO and the Technology Proximity Return } \\
\hline & Q1(Low) & Q2 & Q3 & Q4 & Q5(High) & $\mathrm{H}-\mathrm{L}$ \\
\hline Q1 & -0.370 & 0.226 & 0.132 & $0.765^{* * *}$ & $1.153^{* * *}$ & $1.524^{* * *}$ \\
\hline (Lowest IO) & $(-1.56)$ & $(1.16)$ & $(0.53)$ & $(2.66)$ & $(3.86)$ & $(5.05)$ \\
\hline \multirow[t]{2}{*}{ Q2 } & -0.136 & 0.010 & $0.431 * * *$ & $0.649 * * *$ & $1.014 * * *$ & $1.150 * * *$ \\
\hline & $(-0.73)$ & $(0.06)$ & (3.02) & (3.50) & (4.09) & (3.61) \\
\hline \multirow[t]{2}{*}{ Q3 } & -0.109 & -0.000 & $0.277^{* *}$ & $0.534^{* * *}$ & $0.730 * * *$ & $0.839 * * *$ \\
\hline & $(-0.66)$ & $(-0.00)$ & $(2.37)$ & $(3.46)$ & (3.87) & $(3.47)$ \\
\hline \multirow[t]{2}{*}{ Q4 } & -0.002 & 0.100 & 0.099 & 0.240 & $0.401^{* * *}$ & $0.403 * *$ \\
\hline & $(-0.02)$ & $(0.84)$ & $(0.94)$ & (1.57) & $(2.75)$ & (2.09) \\
\hline Q5 & 0.002 & 0.069 & 0.072 & 0.221 & $0.518 * * *$ & $0.516^{* *}$ \\
\hline (Highest IO) & $(0.01)$ & $(0.60)$ & $(0.55)$ & $(1.49)$ & $(2.87)$ & $(2.40)$ \\
\hline
\end{tabular}

\begin{tabular}{ccccccc}
\multicolumn{8}{c}{ Panel C: Double-Sorted by AF and the Technology Proximity Return } \\
\hline & Q1(Low) & Q2 & Q3 & Q4 & Q5(High) & H-L \\
\hline Q1 & $-0.508^{* *}$ & -0.013 & 0.224 & $0.710^{* * *}$ & $0.931^{* * *}$ & $1.439 * * *$
\end{tabular}




\begin{tabular}{cllllll} 
(Lowest AF) & $(-2.44)$ & $(-0.07)$ & $(1.02)$ & $(3.12)$ & $(3.02)$ & $(4.34)$ \\
Q2 & $-0.299^{*}$ & 0.033 & $0.300^{*}$ & $0.721^{* * *}$ & $1.014^{* * *}$ & $1.313^{* * *}$ \\
& $(-1.71)$ & $(0.19)$ & $(1.91)$ & $(3.22)$ & $(4.31)$ & $(4.67)$ \\
Q3 & -0.146 & 0.122 & $0.455^{* * *}$ & 0.097 & $0.618^{* * *}$ & $0.764^{* *}$ \\
& $(-0.81)$ & $(0.79)$ & $(3.15)$ & $(0.59)$ & $(3.06)$ & $(2.52)$ \\
Q4 & 0.016 & $0.264 * *$ & 0.075 & $0.482^{* * *}$ & $0.619^{* * *}$ & $0.603^{* *}$ \\
& $(0.10)$ & $(2.45)$ & $(0.62)$ & $(3.01)$ & $(3.50)$ & $(2.37)$ \\
Q5 & -0.070 & 0.186 & 0.221 & $0.319^{* *}$ & $0.652^{* * *}$ & $0.722^{* * *}$ \\
(Highest AF) & $(-0.37)$ & $(1.43)$ & $(1.48)$ & $(2.46)$ & $(3.85)$ & $(2.93)$ \\
\hline
\end{tabular}




\section{Table 6 \\ Fama-MacBeth Regressions}

This table reports monthly abnormal returns of a portfolio constructed using Fama-MacBeth forecasting regressions of individual stock returns. The dependent variable is this month's return of a firm. The independent variables are the technology-proximity-weighted portfolio return in month $\mathrm{t}-1(\mathrm{t}-2, \mathrm{t}-3)$ and from t-6 to t-1, TPWRET $T_{t-1}\left(T P W R E T_{t-2}, T P W R E T_{t-3}\right)$ and TPWRET $T_{t-1, t-6}$. These technology-proximityweighted portfolios include all technology-linked firms. The independent variables are also the firm's corresponding equal-weight portfolio return in month $\mathrm{t}-1, E W R E T_{t-1}$, and the firm characteristics which include firm size as measured by the log of the market capitalization at the end of last month (InME), the log of the book-to-market ratio $(\ln (B E / M E))$, the firm's last month return $\left(R E T_{t-1}\right)$ to control for the shortterm reversal effect (Jegadeesh (1990)), and the firm's own past seven-month return not including the last month return ( $R E T_{t-2, t-7)}$ to control for price predictability effect (Jegadeesh and Titman (1993)). We report the time-series averages of cross-sectional regression coefficients and the associated $t$-statistics using the Newey-West (1987) standard errors. Returns and alphas are in monthly percent, $t$-statistics are shown below the coefficient estimates, and $1 \%(5 \%$ and $10 \%)$ statistical significance is indicated by $* * *$ $(* *$ and $*)$.

\begin{tabular}{|c|c|c|c|c|c|}
\hline & $(1)$ & $(2)$ & (3) & $(4)$ & (5) \\
\hline TPWRET $_{t-1}$ & $\begin{array}{c}0.049 * * * \\
(5.41)\end{array}$ & $\begin{array}{c}0.065 * * * \\
(8.18)\end{array}$ & $\begin{array}{c}0.067 * * * \\
(8.75)\end{array}$ & & \\
\hline TPWRET $_{t-2}$ & & & $\begin{array}{c}0.024 * * * \\
(2.93)\end{array}$ & & \\
\hline TPWRET $_{t-3}$ & & & $\begin{array}{c}0.016^{* *} \\
(2.12)\end{array}$ & & \\
\hline$E_{W R E T_{t-1}}$ & & & & $\begin{array}{c}0.066 * * * \\
(8.34)\end{array}$ & \\
\hline$T P W R E T_{t-1, t-6}$ & & & & & $\begin{array}{c}0.022 * * * \\
(6.50)\end{array}$ \\
\hline $\ln M E$ & & $\begin{array}{c}-0.036 * \\
(-1.72)\end{array}$ & $\begin{array}{c}-0.036 * \\
(-1.75)\end{array}$ & $\begin{array}{c}-0.036 * \\
(-1.71)\end{array}$ & $\begin{array}{c}-0.039 * \\
(-1.85)\end{array}$ \\
\hline $\ln (B E / M E)$ & & $\begin{array}{c}0.174 * * * \\
(2.65)\end{array}$ & $\begin{array}{c}0.175^{* * *} \\
(2.73)\end{array}$ & $\begin{array}{c}0.175^{* * *} \\
(2.67)\end{array}$ & $\begin{array}{c}0.167 * * \\
(2.55)\end{array}$ \\
\hline$R E T_{t-2, t-7}$ & & $\begin{array}{l}0.002 \\
(0.93)\end{array}$ & $\begin{array}{l}0.002 \\
(0.80)\end{array}$ & $\begin{array}{l}0.002 \\
(0.92)\end{array}$ & $\begin{array}{l}0.001 \\
(0.64)\end{array}$ \\
\hline$R E T_{t-1}$ & & $\begin{array}{c}-0.062 * * * \\
(-14.45)\end{array}$ & $\begin{array}{c}-0.062 * * * \\
(-14.45)\end{array}$ & $\begin{array}{c}-0.061^{* * *} \\
(-14.44)\end{array}$ & $\begin{array}{c}-0.061 * * * \\
(-14.20)\end{array}$ \\
\hline Constant & $\begin{array}{l}-0.054 \\
(-0.84)\end{array}$ & $\begin{array}{r}0.431 \\
(1.56)\end{array}$ & $\begin{array}{c}0.496^{*} \\
(1.78)\end{array}$ & $\begin{array}{l}0.427 \\
(1.54)\end{array}$ & $\begin{array}{c}0.494^{*} \\
(1.75)\end{array}$ \\
\hline
\end{tabular}




\section{Table 7}

\section{Fama-MacBeth Regressions of Industry Effects}

This table reports monthly abnormal returns of a portfolio constructed using Fama-MacBeth forecasting regressions of individual stock returns. The dependent variable is this month's return of a firm. The independent variables are the VWRET_FF48 $8_{t-1}$, the value-weight return of FF 48 portfolios in month $\mathrm{t}-1$, where the portfolio includes all firms in the same FF 48 industry, TPVWRET_FF48 $8_{t-1}$, the technologylinked return of FF 48 value-weight portfolios in month t-1, EWRET_FF12_P1 $1_{t-1}, E W R E T_{-} F F 12_{-} P 2_{t-1}$, $E W R E T \_F F 12 \_P 3_{t-1}$, the equal-weight return of FF 12 portfolios in month t-1 of the top 30\%, middle $40 \%$, and bottom $30 \%$ sorted by size respectively, TPVWRET_FF48 $8_{t-1}$ with TPEWRET_FF12_P1 $1_{t-1}$, TPEWRET_FF12_P2 $2_{t-1}, T P E W R E T \_F F 12 \_P 3_{t-1}$, the technology-linked and equal-weight return of FF 12 portfolios in month t-1 of the top $30 \%$, middle $40 \%$, and bottom $30 \%$ sorted by size respectively, and the firm characteristics which include firm size as measured by the log of the market capitalization at the end of last month $(\ln M E)$, the $\log$ of the book-to-market ratio $(\ln (B E / M E))$, the firm's last month return $\left(R E T_{t-1}\right)$ to control for the short-term reversal effect (Jegadeesh (1990)), and the firm's own past sevenmonth return not including the last month return $\left(R E T_{t-2, t-7}\right)$ to control for price predictability effect (Jegadeesh and Titman (1993)). We report the time-series averages of cross-sectional regression coefficients and the associated $t$-statistics using the Newey-West (1987) standard errors. Returns and alphas are in monthly percent, $t$-statistics are shown below the coefficient estimates, and $1 \%$ (5\% and $10 \%)$ statistical significance is indicated by $* * *(* * a n d *)$.

\begin{tabular}{|c|c|c|c|c|c|c|c|}
\hline & $(1)$ & $(2)$ & (3) & $(4)$ & $(5)$ & $(6)$ & $(7)$ \\
\hline TPWRET $_{t-1}$ & $\begin{array}{c}0.055^{* * *} \\
(7.19)\end{array}$ & $\begin{array}{c}0.050 * * * \\
(6.66)\end{array}$ & $\begin{array}{c}0.049 * * * \\
(6.41)\end{array}$ & $\begin{array}{c}0.054 * * * \\
(7.76)\end{array}$ & $\begin{array}{c}0.051 * * * \\
(7.28)\end{array}$ & $\begin{array}{c}0.050 * * * \\
(7.10)\end{array}$ & $\begin{array}{c}0.043 * * * \\
(6.02)\end{array}$ \\
\hline VWRET_FF48 $8_{t-1}$ & $\begin{array}{c}0.065^{* * * *} \\
(6.07)\end{array}$ & & $\begin{array}{c}0.059 * * * \\
(6.86)\end{array}$ & & & & $\begin{array}{c}0.046 * * * \\
(5.24)\end{array}$ \\
\hline TPVWRET_FF48 ${ }_{t-1}$ & & $\begin{array}{c}0.090 * * * \\
(3.64)\end{array}$ & $\begin{array}{c}0.037 * \\
(1.79)\end{array}$ & & & & $\begin{array}{l}0.024 \\
(0.99)\end{array}$ \\
\hline$E W R E T \_F F 12 \_P 1_{t-1}$ & & & & $\begin{array}{c}0.040 * * * \\
(3.26)\end{array}$ & & $\begin{array}{c}0.037 * * * \\
(3.08)\end{array}$ & $\begin{array}{c}0.036 * * * \\
(2.82)\end{array}$ \\
\hline$E W R E T \_F F 12 \_P 2_{t-1}$ & & & & $\begin{array}{c}0.061^{* * *} \\
(2.65)\end{array}$ & & $\begin{array}{c}0.061^{* * *} \\
(2.98)\end{array}$ & $\begin{array}{c}0.059 * * * \\
(2.92)\end{array}$ \\
\hline$E W R E T \_F F 12 \_P 3_{t-1}$ & & & & $\begin{array}{c}0.058 * * \\
(2.40)\end{array}$ & & $\begin{array}{c}0.042^{* *} \\
(1.99)\end{array}$ & $\begin{array}{l}0.014 \\
(0.64)\end{array}$ \\
\hline TPEWRET_FF12_P1 $1_{t-1}$ & & & & & $\begin{array}{c}0.066 * \\
(1.92)\end{array}$ & $\begin{array}{l}0.029 \\
(0.84)\end{array}$ & $\begin{array}{l}0.017 \\
(0.49)\end{array}$ \\
\hline TPEWRET_FF12_P2 $2_{t-1}$ & & & & & $\begin{array}{l}0.040 \\
(0.78)\end{array}$ & $\begin{array}{l}-0.010 \\
(-0.20)\end{array}$ & $\begin{array}{l}-0.002 \\
(-0.04)\end{array}$ \\
\hline TPEWRET_FF12_P3 $3_{t-1}$ & & & & & $\begin{array}{c}0.114^{* *} \\
(2.34)\end{array}$ & $\begin{array}{l}0.068 \\
(1.51)\end{array}$ & $\begin{array}{l}0.028 \\
(0.54)\end{array}$ \\
\hline $\ln M E$ & $\begin{array}{c}-0.037 * \\
(-1.77)\end{array}$ & $\begin{array}{c}-0.037 * \\
(-1.82)\end{array}$ & $\begin{array}{c}-0.037^{*} \\
(-1.80)\end{array}$ & $\begin{array}{l}-0.027 \\
(-1.37)\end{array}$ & $\begin{array}{c}-0.035^{*} \\
(-1.75)\end{array}$ & $\begin{array}{l}-0.027 \\
(-1.37)\end{array}$ & $\begin{array}{l}-0.030 \\
(-1.52)\end{array}$ \\
\hline $\ln (B E / M E)$ & $0.169 * * *$ & $0.177 * * *$ & $0.172 * * *$ & $0.208 * * *$ & $0.205 * * *$ & $0.216^{* * *}$ & $0.217 * * *$ \\
\hline
\end{tabular}




\begin{tabular}{lccccccc} 
& $(2.61)$ & $(2.79)$ & $(2.72)$ & $(3.42)$ & $(3.39)$ & $(3.66)$ & $(3.72)$ \\
$R E T_{t-2, t-7}$ & 0.001 & 0.002 & 0.001 & 0.001 & 0.002 & 0.001 & 0.001 \\
& $(0.59)$ & $(0.84)$ & $(0.55)$ & $(0.58)$ & $(0.85)$ & $(0.58)$ & $(0.43)$ \\
$R E T_{t-1}$ & $0.064^{* * *}$ & $0.062^{* * *}$ & $0.064 * * *$ & $0.064 * * *$ & $0.062 * * *$ & $0.064^{* * *}$ & $0.065^{* * *}$ \\
& $(-14.39)$ & $(-14.48)$ & $(-14.40)$ & $(-14.60)$ & $(-14.54)$ & $(-14.60)$ & $(-14.59)$ \\
Constant & $0.478^{*}$ & $0.540^{*}$ & $0.538^{*}$ & 0.160 & 0.254 & 0.149 & 0.330 \\
& $(1.70)$ & $(1.88)$ & $(1.84)$ & $(0.54)$ & $(0.81)$ & $(0.45)$ & $(1.01)$ \\
\hline
\end{tabular}


Table 8

Technology-Based Strategy, Controlling for Intra-Cluster Effects

This table reports the calendar-time portfolio abnormal excess returns for four subsample periods. At the beginning of every calendar month, stocks are ranked in ascending order by technology proximity return at the end of the previous month, excluding the firms in the same FF-48, FF12, SA, CS, the combination of FF-48, SA and CS, the combination of FF-12, SA and CA, respectively. The ranked stocks are assigned to one of five quintile portfolios. All stocks are equal weighted within a given portfolio, and the portfolios are rebalanced every calendar month to maintain equal weights. This table includes all available stocks with stock price greater than $\$ 1$ at portfolio formation. H-L is the alpha of a zero-cost portfolio that holds the top quintile technology-linked stocks and sells short the bottom quintile technology-linked return stocks. Returns and alphas are in monthly percent, $t$-statistics are shown below the coefficient estimates, and $1 \%(5 \%$ and $10 \%)$ statistical significance is indicated by $* * *(* *$ and $*)$.

\begin{tabular}{ccccccc}
\hline Excluding & Q1(Low) & Q2 & Q3 & Q4 & Q5(High) & H-L \\
\hline FF48 & -0.027 & 0.056 & $0.260^{* * *}$ & $0.369^{* * *}$ & $0.675^{* * *}$ & $0.703^{* * *}$ \\
& $(-0.30)$ & $(0.69)$ & $(3.15)$ & $(4.01)$ & $(5.86)$ & $(5.34)$ \\
FF12 & -0.008 & 0.137 & $0.253^{* * *}$ & $0.405^{* * *}$ & $0.522^{* * *}$ & $0.530^{* * *}$ \\
& $(-0.08)$ & $(1.64)$ & $(3.07)$ & $(3.98)$ & $(5.87)$ & $(4.56)$ \\
SA & -0.117 & 0.072 & $0.297^{* *}$ & $0.585^{* * *}$ & $0.866^{* * *}$ & $0.982^{* * *}$ \\
& $(-0.72)$ & $(0.64)$ & $(2.36)$ & $(3.21)$ & $(3.67)$ & $(3.35)$ \\
CS & -0.152 & 0.079 & $0.262^{* * *}$ & $0.458^{* * *}$ & $0.757 * * *$ & $0.909^{* * *}$ \\
& $(-1.22)$ & $(0.91)$ & $(2.81)$ & $(3.48)$ & $(4.31)$ & $(4.12)$ \\
FF48,SA,CA & 0.012 & 0.130 & $0.300^{* *}$ & $0.438^{* * *}$ & $0.810^{* * *}$ & $0.798^{* * *}$ \\
& $(0.09)$ & $(0.97)$ & $(2.19)$ & $(2.77)$ & $(4.15)$ & $(3.78)$ \\
FF12,SA,CS & 0.048 & $0.227 *$ & $0.339^{* *}$ & $0.477^{* * *}$ & $0.578^{* * *}$ & $0.530^{* * *}$ \\
& $(0.29)$ & $(1.68)$ & $(2.53)$ & $(2.66)$ & $(4.35)$ & $(3.14)$ \\
\hline
\end{tabular}


Table 9

Technology-Based Strategy and Technology Diversity

Panel A of this table reports the calendar-time portfolio abnormal excess returns for portfolios doublesorted by technology diversity (defined in Hirshleifer et al (2013)) and technology proximity return. At the beginning of every calendar month, stocks are ranked in ascending order first by technology diversity and then by technology proximity return at the end of the previous month. The ranked stocks are assigned to one of 3 by 5 quintile portfolios. All stocks are equal weighted within a given portfolio, and the portfolios are rebalanced every calendar month to maintain equal weights. This table includes all available stocks with stock price greater than $\$ 1$ at portfolio formation. H-L is the alpha of a zero-cost portfolio that holds the top quintile technology-linked stocks and sells short the bottom quintile technology-linked return stocks. Returns and alphas are in monthly percent, $t$-statistics are shown below the coefficient estimates, and $1 \%(5 \%$ and $10 \%)$ statistical significance is indicated by $* * *(* *$ and $*)$. Panel B of this table reports monthly abnormal returns of a portfolio constructed using Fama-MacBeth forecasting regressions of individual stock returns. The dependent variable is this month's return of a firm. In Column (1), the independent variables are the technology-proximity-weighted portfolio returns in month t-1 of the five quintiles (TPWRETt-1_Q1, TPWRETt-1_Q2, TPWRETt-1_Q3, TPWRETt-1_Q4, and TPWRETt-1_Q5). In Column (2), the technology-proximity-weighted portfolio returns in month t-1 of the tercile portfolios sorted by technology diversity (TPWRETt-1_TD_P1, TPWRETt-1_TD_P2, and TPWRETt-1_TD_P3). In Column (3), besides the independent variables in Column (2), we also add the returns of the EW tercile portfolios of the technology related firms in the same FF-12 industry (EWRETt1_FF12_P1, EWRETt-1_FF12_P2, and EWRETt-1_FF12_P3), add the technology-proximity tercile portfolios of the technology related firms in the same FF-12 industry (TPWRETt-1_FF12_P1, TPWRETt1_FF12_P2, and TPWRETt-1_FF12_P3). The firm characteristics include firm size as measured by the $\log$ of the market capitalization at the end of last month $(\ln M E)$, the log of the book-to-market ratio $(\ln (B E / M E))$, the firm's last month return $\left(R E T_{t-1}\right)$ to control for the short-term reversal effect (Jegadeesh (1990)), and the firm's own past seven-month return not including the last month return $\left(R E T_{t-2, t-7)}\right.$ to control for price predictability effect (Jegadeesh and Titman (1993)). We report the time-series averages of cross-sectional regression coefficients and the associated t-statistics using the Newey-West (1987) standard errors. Returns and alphas are in monthly percent, $t$-statistics are shown below the coefficient estimates, and $1 \%$ (5\% and 10\%) statistical significance is indicated by $* * *(* *$ and $*)$.

\begin{tabular}{|c|c|c|c|c|c|c|}
\hline & \multicolumn{6}{|c|}{$\begin{array}{c}\text { Panel A: Double Sort by Technology Diversity and Technology Proximity } \\
\text { Return }\end{array}$} \\
\hline & Q1(Low) & Q2 & Q3 & Q4 & Q5(High) & H-L \\
\hline \multirow[t]{2}{*}{ Lowest Technology Diversity } & 0.047 & $0.120^{*}$ & $0.244 * * *$ & $0.403^{* * *}$ & $0.546 * * *$ & $0.500 * * *$ \\
\hline & $(0.53)$ & $(1.85)$ & (3.19) & $(3.90)$ & $(4.56)$ & $(4.51)$ \\
\hline \multirow[t]{2}{*}{ Medium Technology Diversity } & 0.004 & 0.126 & $0.242 * * *$ & $0.449 * * *$ & $0.565 * * *$ & $0.561 * * *$ \\
\hline & $(0.05)$ & $(1.56)$ & $(3.12)$ & $(4.32)$ & $(4.70)$ & $(4.32)$ \\
\hline \multirow[t]{4}{*}{ Highest Technology Diversity } & -0.072 & 0.031 & $0.203^{* *}$ & $0.498 * * *$ & $0.681 * * *$ & $0.753^{* * *}$ \\
\hline & $(-0.64)$ & $(0.39)$ & $(2.55)$ & $(4.51)$ & $(5.75)$ & $(4.69)$ \\
\hline & \multicolumn{6}{|c|}{ Panel B: Fama-MacBeth Regression } \\
\hline & \multicolumn{2}{|l|}{$(1)$} & \multicolumn{2}{|c|}{$(2)$} & \multicolumn{2}{|l|}{ (3) } \\
\hline WRETt-1_Q1 & \multicolumn{2}{|c|}{$\begin{array}{l}0.009 \\
(0.85)\end{array}$} & & & & \\
\hline
\end{tabular}




$\begin{array}{cc}\text { TPWRETt-1_Q2 } & 0.005 \\ & (0.47) \\ \text { TPWRETt-1_Q3 } & 0.010 \\ & (1.08) \\ \text { TPWRETt-1_Q4 } & 0.014^{*} \\ & (1.66) \\ \text { TPWRETt-1_Q5 } & 0.068^{* * *} \\ & (8.00)\end{array}$

TPWRETt-1_TD_P1

TPWRETt-1_TD_P2

TPWRETt-1_TD_P3

EWRETt-1_FF12_P1

EWRETt-1_FF12_P2

EWRETt-1_FF12_P3

TPWRETt-1_FF12_P1

TPWRETt-1_FF12_P2

TPWRETt-1_FF12_P3

$\ln M E$

$\ln (B E / M E)$

$R E T_{t-2, t-7}$

$R E T_{t-1}$

Constant

0.005

$(0.47)$

0.010

(1.08)

$0.014^{*}$

$0.068 * * *$

$(8.00)$
$0.015^{* * *}$
$(4.48)$
$0.025^{* * *}$
$(5.38)$
$0.036^{* * *}$

(5.10)

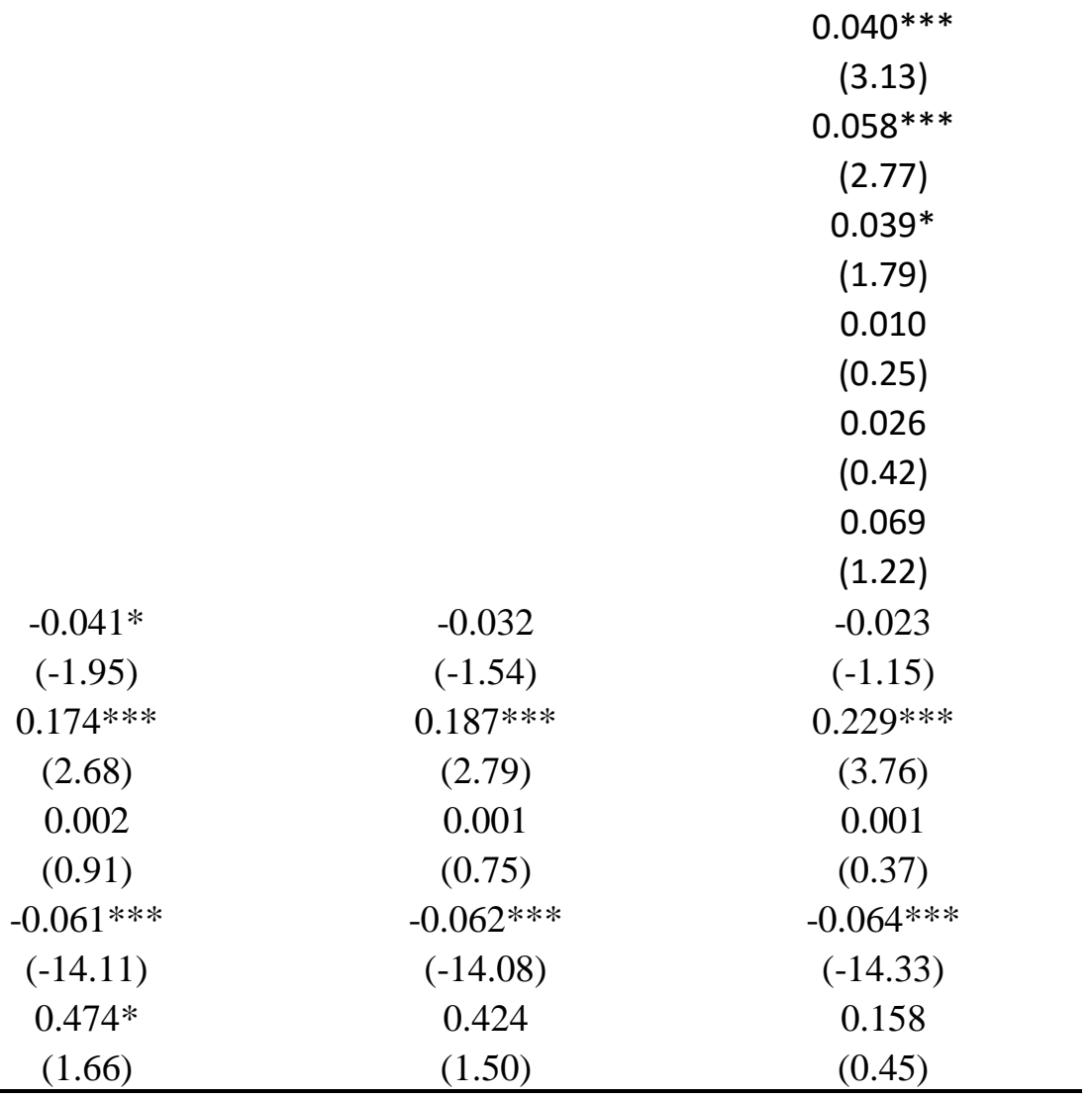


Table 10

Technological Relatedness and Operational Performance

This table examines whether technology related firms are correlated in operational performance. The dependent variable is the firm level's ROA. The independent variables are the assets-weighted average ROA of all firms and the assets-weighted average ROA of the technology related firms. We report the time-series averages of cross-sectional regression coefficients and the associated $t$-statistics using the Newey-West (1987) standard errors. Returns and alphas are in monthly percent, $t$-statistics are shown below the coefficient estimates, and $1 \%$ (5\% and 10\%) statistical significance is indicated by $* * *(* *$ and $*)$.

\begin{tabular}{cccccccc}
\hline & $(1)$ & $(2)$ & $(3)$ & $(4)$ & $(5)$ & $(6)$ & $(7)$ \\
\hline \multirow{2}{*}{ ROA All firms } & $1.539^{* * *}$ & $2.841^{* * *}$ & $3.129^{* * *}$ & 0.539 & 2.111 & 0.536 & 0.536 \\
& $(2.65)$ & $(4.56)$ & $(4.97)$ & $(0.91)$ & $(1.53)$ & $(0.90)$ & $(0.88)$ \\
\multirow{2}{*}{ ROA Related firms } & $0.599^{* * *}$ & $0.338^{* * *}$ & $0.278^{* * *}$ & $0.456^{* * *}$ & $0.524^{* * *}$ & $0.283^{* * *}$ & $0.244^{* * *}$ \\
& $(15.03)$ & $(9.53)$ & $(7.83)$ & $(10.54)$ & $(13.11)$ & $(7.56)$ & $(6.41)$ \\
Constant & $-0.127^{* *}$ & $0.244^{* * *}$ & $0.268^{* * *}$ & -0.039 & -0.181 & -0.037 & -0.036 \\
& $(-2.11)$ & $(-3.80)$ & $(-4.13)$ & $(-0.77)$ & $(-1.35)$ & $(-0.73)$ & $(-0.69)$ \\
\hline
\end{tabular}

